\author{
$\mathfrak{D a 8}$ \\ Cransport- Melen \\ Dอยี

\section{Prenzifiden Stantes} \\ ober \\ bie (Stueral $=$ Trmuşport $=$ Juitruftion voun 16 . Sept. 1816

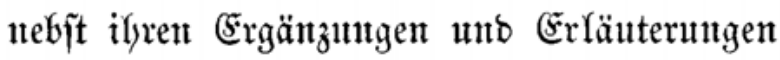 \\ fowie \\ in ibren Beşichungen zum Auglande. \\ Pad amtiaben Quellen mit Rommentar \\ berausgegeben \\ von \\ (5.) D D P $\mathfrak{l}$, \\ söniвเ Pofizei:beamter.
}

\title{
亩erlin.
}

Berlag yon $\mathfrak{J}$. (S) Htentag.

1864. 
